\title{
Look for the helpers
}

\section{Richard B. Gunderman ${ }^{1}$}

Received: 12 May 2020 / Revised: 12 May 2020 / Accepted: 15 June 2020 / Published online: 30 June 2020

(C) Springer-Verlag GmbH Germany, part of Springer Nature 2020

Fred Rogers, creator and host of the long-running children's television program "Mr. Rogers' Neighborhood," liked to share some advice his mother gave him when he was a child. Rogers would see things in the news that distressed him and ask his mother what to do. Her advice: "Look for the helpers. You will always find people who are helping" [1].

In times of disruption such as the COVID-19 pandemic, it is natural to emphasize fears and anxieties. Yet the things radiology personnel have to fear are only part of the story most disruptions bring not only hazard but also opportunity, and opportunity not only for others but for each pediatric radiologist. We can not only look for the helpers but become helpers in our own right.

Of course, pediatric radiology personnel help by simply doing our jobs. By continuing to show up at work, interpret imaging studies, perform procedures and push forward with education, research, and professional service, we serve others in many ways. But disruptions such as a pandemic remind us of opportunities to serve in ways that extend beyond radiologic and even medical expertise.

Especially important in this regard are service opportunities that do not involve payment for services rendered. So long as radiology personnel remain on the job, we continue to be compensated. But a pandemic helps to reveal needs around us that, when met, provide no remuneration but immense rewards in knowing we have made a difference.

Consider the case of Helmut Diefenthal, a Minnesota radiologist who died in 2019 at the age of 95 [2]. Born in Berlin in 1919, Diefenthal was drafted into service in the German army during World War II, after which he trained in medicine and married. He and his wife then began service as missionaries in Malaysia, later moving to Tanzania.

Richard B. Gunderman

rbgunder@iu.edu

1 Department of Radiology, Indiana University, 702 North Barnhill Drive, Room 1053, Indianapolis, IN 46202, USA
With plans underway to construct a new hospital in Tanzania, Diefenthal decided that he needed to pursue training in radiology. So he and his family moved to Minneapolis, where he completed a diagnostic radiology residency and his wife trained as a radiologic technologist. After completing the training, the Diefenthals returned to Tanzania.

Some years later, the Diefenthals came back to Minneapolis, where he worked in the Veterans Administration Hospital, retiring in 1988. Thereafter, Diefenthal returned to Tanzania, helping to improve the quality of radiology services and also introducing ultrasound to the hospital. In 1993, he began training programs there for both technologists and radiologists.

Diefenthal's dedication to service had its roots in a disruption he had not only witnessed but suffered personally. On a train as a member of the German military during World War II, Diefenthal was about to become part of perhaps the greatest military disaster of the entire war, the Siege of Stalingrad [3]. He made a promise to God. If he survived the Russians and the war, he would devote his life to service.

Of course, Diefenthal survived. By the time his train was approaching, the Russians had already surrounded the occupying German troops, so the train was diverted to Kiev. Unlike Diefenthal, an estimated 800,000 Axis troops were killed, wounded, missing or captured. Soviet military and civilian casualties have been estimated at 1.1 million.

When Diefenthal returned to Germany for medical training, he attended a church whose pastor composed words now read around the world. The pastor's name was Martin Niemöller, and his words read:

First they came for the Socialists, and I did not speak out, because I was not a Socialist. Then they came for the Trade Unionists, and I did not speak out, because I was not a Trade Unionist. Then they came for the Jews, and I did not speak out, because I was not a Jew. Then they came for me - and there was no one left to speak for me [4]. 
Why decades later did Diefenthal, having retired, decide to return to Africa? He and his wife did so not because it was an attractive proposition financially, but to answer a call. "We were both over 65. But my wife had her Social Security, and I had my pension and Social Security, and that allowed us to go back to Tanzania, even though no one would pay us" [5].

One way to look at Diefenthal's choices is through the lens of economics. His skills as a radiologist and teacher could be valued in dollars, and an economist might ask, "What would constitute a reasonable rate of compensation for his services?" To answer that question, the economist would look to the marketplace, to see what others pay for the work of radiologists.

But Diefenthal saw the opportunity in another way. His goal was not to extract sufficient value from the people of Tanzania or those funding his services. His goal was to serve, and when it came to money, the only question he needed to ask was this: Would he and his wife have enough? So long as the answer was yes, he could stop thinking about money and focus on contributing as much as he could.

In fact, Diefenthal contributed a great deal. At a time when some retired radiology personnel might be thinking about how to spend their money, Diefenthal was working 11- and 12$h$ days, attempting to make the most of his expertise to benefit patients and health professions students. He was not doing a job - he was sharing a gift.

Diefenthal's story offers important insights to radiology personnel in times of disruption such as the COVID-19 pandemic. No one, least of all Diefenthal himself, would say that every person should get on the next flight to a developing nation. But he probably would say that opportunities to share the best we have to offer are more widely available than we commonly suppose.

Someone who approached every encounter with the question, "What's in it for me?" would find the work and life of a man like Diefenthal difficult to comprehend. But pediatric radiologists who recognize that each of us is part of larger wholes - patients, family, profession and so on - see that it is only in service to those larger wholes that we come fully into our own.

When Fred Rogers' mother counseled, "Look for the helpers," she was hinting at perhaps the most effective means of remedying burnout and finding genuinely fulfilling opportunities in life. In looking for the helpers, we are engaged in a kind of exploration, and it is only when we find the helper in ourselves that we unlock our potential to make a difference and find fulfillment in work and life.

\section{Compliance with ethical standards}

\section{Conflicts of interest None}

\section{References}

1. King M (2018) The good neighbor: the life and work of Fred Rogers. Abrams Press, New York

2. Minneapolis Star Tribune (2019) Dr. Helmut Diefenthal (obituary). https://www.startribune.com/obituaries/detail/0000323415/. Accessed 8 June 2020

3. Beevor A (1999) Stalingrad: the fateful siege, 1942-43. Penguin Books, New York

4. Holocaust Memorial Day Trust (2020) First they came - by Pastor Martin Niemöller. https://www.hmd.org.uk/resource/first-theycame-by-pastor-martin-niemoller/

5. Melo F (2016) Son of Jew conscripted by Nazis swore to do good if he survived. He did, and he did. TwinCities Pioneer press. https:// www.twincities.com/2016/12/30/medical-missionary-keepspromise-made-75-years-ago-during-wwii/

Publisher's note Springer Nature remains neutral with regard to jurisdictional claims in published maps and institutional affiliations. 